\title{
STRATEGIC INFORMATION SYSTEMS PLANNING AND INFORMATION TECHNOLOGY FOR SCHOOL
}

\author{
Agus Susilo Nugroho ${ }^{1}$, Wing Wahyu Winarno ${ }^{2}$, Hanif Al Fatta ${ }^{3}$ \\ ${ }^{123}$ Magister Teknik Informatika*, Universitas Amikom Yogyakarta \\ corresponding*agus.nugroho@students.amikom.ac.id; wing@stieykpn.ac.id; \\ hanif.a@amikom.ac.id
}

DOI: https://doi.org/10.21107/Widyagogik/v8i1.8250

Received August 14, 2020; Revised August 18, 2020; Accepted September 21,2020

\begin{abstract}
As a foundation, At-Thoat school has a routine agenda every year, namely the Admission of New Students (ANS). Even though they have implemented by online, they have not been able to realize one day service. The speed and automation of ANS services greatly helps the acquisition of new students. Because competition for new students is competitive. In addition, the number of new students at At-Thoat has also greatly influenced the survival of the school. The solution offered in this study for this problem is to compile a strategic design for Information Systems (IS) and Information Technology (IT) using the Ward and Peppard method, which are design methods capable of producing IS / IT strategies that are in line with business strategies. The first stage in applying this method in this research is the analysis of current conditions, both the organization as a whole and the IS

/ IT aspect. The next stage is an analysis of IS / IT needs in the future. The final stage is the preparation of IS / IT strategic steps. To analyze each of these stages, analysis tools are needed, namely: SWOT, critical success factor. The implementation of the Ward and Peppard methods and their analytical tools were able to identify and recommend IS / IT needs at At-Thoat School for the next 5 years. However, the resulting recommendations must be adjusted to the priority scale, because of the various limitations faced.
\end{abstract}

Keywords - Strategic Information System, planning, Ward and Peppard 
2 Strategic Information Systems Planning and Information Technology for School Agus Susilo Nugroho, Wing Wahyu Winarno, Hanif Al Fatta

\section{Introduction}

At-Thoat school is one of private schools in Grobogan Regency, Central Java. One of operational activities at At-Thoat school is about administration. The Admission of New Student (ASN) is one of the routine administrative activities which is held every new school year. The Admission of New Student at At-Thoat school is done in person (coming to school) and online. However, online registration has not yet been able to realize a one day service. This is important to be realized, because the quickness and automation of ASN services greatly helps the acquisition of new students for At-Thoat School. Because the competition for new students is very competitive. In addition, the number of new students at At-Thoat school also greatly affects for the survival of its school.

Strategic Information System Planning and Information Technology can assist in overcoming these problems. Ward and Peppard's IS / IT strategic design method serves to produce IS / IT strategic plans that can add business value to the organization. Because this method is able to align with the vision and mission of the organization. Tiernan and Peppard (2004) explain the difference between IT positions as funding or expense. They say that value will emerge if business goals can be achieved based on IT implementation as previously expected. In addition, value will be created if the benefits obtained are greater than the costs of obtaining them. Besides, this method can also produce a portfolio of applications that must be realized, thus helping IT investment decisions [1]. Chan, Saberwhan and Thatcher (2006) said that the integration of SI strategy with business will positively contribute to organizational performance, although the impact is not always the same, depending on the type of organization and the business strategy being implemented. They also added that the advantage of integrating business strategy with IS will be even greater if the organization has planned a strong knowledge sharing process [2]. Therefore, a strategic planning for Information Systems / Information Technology (IS/ IT) is needed. Where the IS / IT strategic planning must be in line with the organization's business strategy. The purpose of this research is how to implement the IS / IT strategic plan at At-Thoat school which is in line with the needs of it's school.

According to Iwan Supriyantoko (2019), in business competition, a strategic information system is needed in order to provide an advantage in business activities [3]. The same thing happened in PT. Pos Indonesia Cilegon - Banten. One of these state companies also needs the right business strategy to improve performance and competitiveness (Anharudin, 2015) [4]. Although many companies have implemented IS/ IT, there are still many gaps due to the inaccurate implementation of IS / IT in supporting the company's business activities. Therefore, it is necessary to plan a strategic information system that is appropriate and in line with the company's business development, so that it can provide a competitive advantage (Suwirno and Noviadi, 2015) [5]. 
On the other hand, in order for information to be managed properly, it is necessary to have an adequate ICT-based system (Irfan and Abdi, 2016) [6]. The success of an organization is influenced by information systems and information technology (IS / IT). Even though there is IS / IT, if it is not used optimally, it will cause the data to not be well organized. Therefore it needs the right IS / IT according to the needs of the organization. This can be started by making an IS / IT strategic plan (Yunita, Adi and Agustinus, 2018) [7]. The existence of new demands in an organization causes a paradigm shift in managing IT. When the ongoing IT management is deemed inadequate, it is necessary to have an information system and information technology strategic plan that is in line with the business strategy (Purnomo and Febriliyan, 2017) [8]. In an organization, there is always information generated from various activities, both internal and external. It need a strategic plan to support the company's vision, mission and goals. The strategy needed to be supported the latest information to help company information systems better (Putu Widiadnyana, Ari Putra Wijaya and Ida Bagus Manuaba, 2016) [9]. The application of information systems and information technology is a long-term investment. This investment requires enormous financial support. Often the application of information technology has failed. Therefore a structured strategic planning is needed (Nicka Puspita Sriminangga and Febriliyan Samopa, 2017) [10].

\section{Method}

In collecting data, researchers used four methods, namely interviews, observation, document studies and literature studies. Interviews were conducted with the principal of At-Thoat and related staff who handle the admission of new student. The interview result data is qualitative. In observation, the researcher made direct observations of the object of research, in this case At-Thoat school. The data obtained are qualitative. For document study, the research was conducted by reviewing the supporting documents found at At- Thoat school. The data from the document review can be in the form of qualitative or quantitative data. Literature studies are carried out by examining other studies on the same topic. In addition, by reviewing books on IS / IT strategic planning. From the data collected, it will then be described in a Ward and Peppard research method supported by analysis tools, namely: SWOT and critical success factors. This research was conducted in six stages. The six stages start from the preliminary stage, the stage of data collection, the stage of understanding the current situation, the stage of determining the need for the future, the stage of strategies formulation, and giving application portofolio. 
4 Strategic Information Systems Planning and Information Technology for School Agus Susilo Nugroho, Wing Wahyu Winarno, Hanif Al Fatta

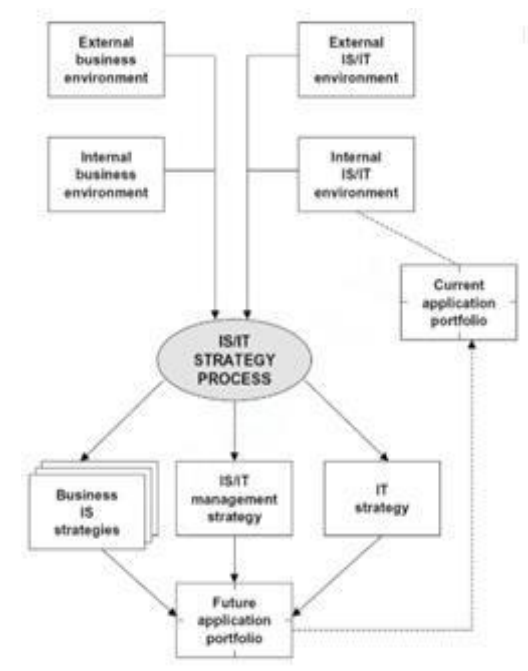

Figure 1. Ward and Peppard method

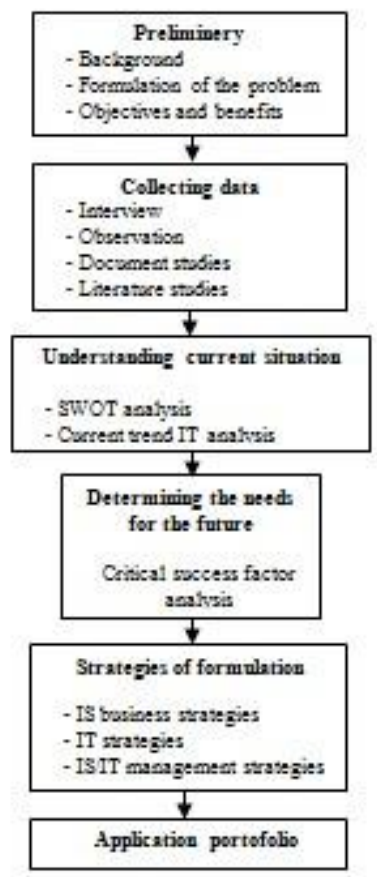

Figure 2. The stage of research

Preliminary stage: Is the initial stage in research. At this stage, the research background, problem formulation, research objectives and benefits will be determined.

Data collection stage: To carry out research, it is necessary to have valid data that must be reviewed. This data will be obtained through interviews with the head of At-Thoat school, direct observation at At-Thoat school, 
document studies and literature studies. Understanding the current situation stage: This stage aims to understand the current situation that is being faced by the organization as a whole, both internally and externally, including the IS / IT aspect. It will be reviewed to produce a SWOT anaylisis. To strengthen the analysis, researchers had observed the current technlogy issues. The stage of determining the needs for the future: At this stage, the research examines the conditions of IS / IT that are desired in the future, and what is needed to achieve this. The analytical method used is critical success factor.

Strategies of formulation stage: At this stage the IS / IT strategy will be formulated. There are three resulting strategies, namely: IS business IS strategies, IT strategies and IS / IT management strategies. Business strategy will be a reference to ensure IS in order to support the achievement of business goals. The IT strategies will become the standard for infrastructure / hardware development as well as HR development so that IS will run as expected. And finally, the IS / IT management strategies will become a recommendation for IS / IT management. Application portfolio stage: This research is also expected to be able to produce an application portfolio that can be used as a reference for any applications needed in the future. This portfolio is structured based on SWOT anaylisis and critical success factor analysis. To verify the portofolio, researcher will take some survey with the head master of school. And it will adjusting with the policy of school.

\section{Result and Discussion}

Analysis of the conditions of the internal business environment of At- Thoat school provides an overview of its strengths and weaknesses. Meanwhile, the analysis of the external business environment conditions of AtThoat school presents an overview of the opportunities and threats faced. The use of SWOT analysis is intended to determine the strategic position of AtThoat school. The results are shown in Figure 3 below: 


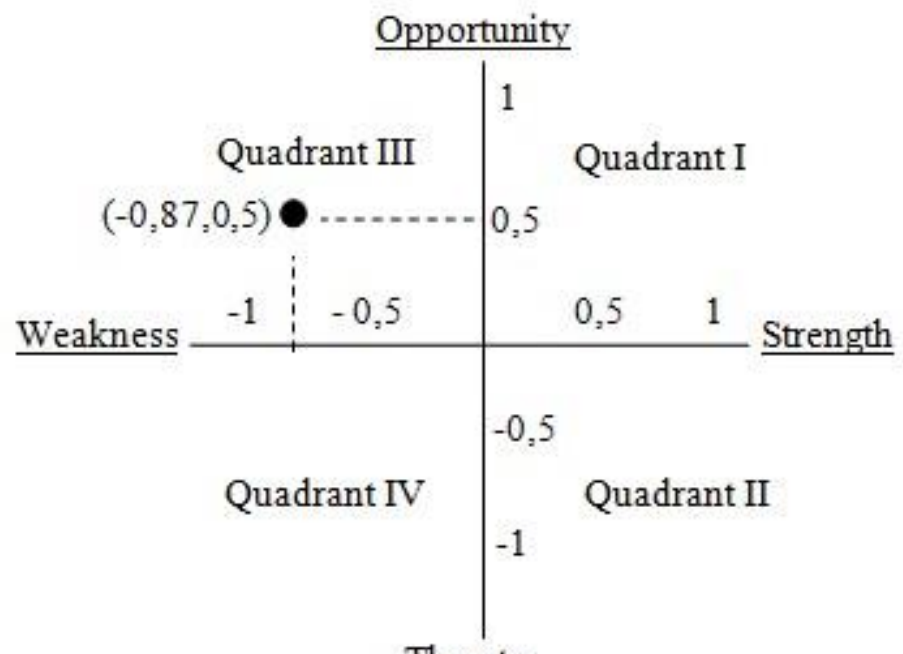

Threats

Figure 3. The position of At-Thoat school in SWOT quadrant

From Figure 3 it can be concluded that At-Thoat school is in quadrant III with a coordinate point $(-0.87,0.5)$. In other words, At-Thoat school needs to utilize and increase internal strength as a measure to anticipate threats that occur. At-Thoat school also needs to cover its weaknesses, because the difference between strength and weakness still minus. After knowing the location At-Thoat school in the SWOT quadrant, the next process is the identification of the Critical Success Factor (CSF). Where the results of this CSF will be used as material for the analysis of IS / IT needs at At-Thoat school. Identification of Critical Success Factors (CSF) resulted in 3 CSFs for At-Thoat school. The result is shown in table 1 below:

Table 1. CSF At-Thoat school

\begin{tabular}{|c|l|l|}
\hline Code & \multicolumn{1}{|c|}{ Description } & Data and information requirement \\
\hline CSF01 & $\begin{array}{l}\text { By providing assistance and facilities to } \\
\text { teachers in order to have an } \\
\text { educator certificate }\end{array}$ & Teacher main data \\
\hline CSF02 & $\begin{array}{l}\text { By having the admission of new student } \\
\text { online with one day service based. }\end{array}$ & Server, application \\
\hline CSF03 & $\begin{array}{l}\text { By providing assistance and facilities to } \\
\text { teachers in order to get computer training. }\end{array}$ & Computer training system \\
\hline CSF04 & By increasing school achievement. & Teacher and student ability \\
\hline
\end{tabular}




\section{Conclusion}

Based on research conducted at At-thoat school, can be concluded that to improve the competence of At-Thoat school, IS / IT strategic planning is needed. To implement the IS / IT strategic planning that is in line with the needs of At-Thoat school, researcher use Ward and Peppard method that combined with SWOT analysis and critical success factor. Because Ward and Peppard method can be used adjusted with vision and mision At-Thoat school.

\section{References}

[1] Thierman, Chris, and P. Joe, "Information Technology: Of Value or Vulture?" European Management Journal, Vol. 22, No. 6, Hal 609-623, 2004.

[2] Y. E. Chan, R. Sabherwal and J. B. Thatcher, "Antecedents and outcomes of strategic IS alignment: an empirical investigation," in IEEE Transactions on Engineering Management, vol. 53, no. 1, pp. 27-47, Feb. 2006.

[3] I. Supriyantoko, "Perancangan Strategis Sistem Informasi di SMK Diponegoro 1 Jakarta", Elinvo (Electronics, Informatics, and Vocational Education), 3.10-18, November 2019.

[4] Anharudin, "Perencanaan Strategis Sistem Informasi Untuk Meningkatkan Pelayanan Menggunakan Metode Ward and Peppard (Studi Kasus : PT Pos Indonesia Cilegon - Banten)," Jurnal Prosiko, Vol. 2, 2015.

[5] Suwirno and M. Noviadi, "Perencanaan Strategis Sistem Informasi / Teknologi Informasi Pada Perusahaan Penjualan Mobil Dengan Pendekatan John Ward And Joe Peppard Studi Kasus : PT Topcars Cabang Palembang," STMIK GI MDP, 2015.

[6] I. N. Arifani and A. Darmawan, "Perencanaan Strategis Sistem Informasi dan Teknologi Informasi SI/TI Pendidik dan Tenaga Kependidikan (Studi Kasus: Pada Disdikbudpora Metro)," Jurnal TIM Darmajaya, 2016.

[7] Y. Utami, A. F. Wijaya, and A. Nugroho, "Perencanaan Strategis Sistem Informasi dan Teknologi Informasi Pada Dinas Perindustrian dan Tenaga Kerja Kota Salatiga," Jurnal Teknologi Informasi dan Ilmu Komputer, 2018.

[8] P. Y. Dewantara and F. Samopa, "Perencanaan Strategis Sistem Informasi / Teknologi Informasi di Balai Riset dan Strandardisasi Industri Surabaya," Jurnal Teknologi Proses dan Inovasi Industri, Vol. 2, 2017.

[9] P. Widiadnyana, A. P. Wijaya and I. B. Manuaba, "Strategic Information System and Interoganitation Planning." International Journal of Engineering and Emerging Technology, [S.I.], v. 1, n. 1, mar. 2016.

[10] N. Sriminangga and F. Samopa, "Strategic Planning of Information System / Information Technology at KOMINFO Department in Malang," International Journal of Education and Research, Vol. 5 No. 1, January 2017. 